\title{
修飾シクロデキストリンの化学
}

\author{
池 田博*.戸 田 不二緒*
}

\section{Chemistry of Modified Cyclodextrins.}

Hiroshi $\mathrm{IKEDA}^{*}$ and Fujio TODA

\begin{abstract}
Cyclodextrins (CDs) are a series of cyclic and nonreducing oligosaccharides produced by CGTase. They can form inclusion complexes with many kinds of molecules, and fundamental and applied investigations about CD are made in the many fields. CDs are successfully used in various industries, e.g., food, pharmaceutical, cosmetic, and toiletry. By modification of $\mathrm{CD}$, properties of $\mathrm{CD}$ can be changed and poly-functional host molecule can be made.
\end{abstract}

\section{解 説}

シクロデキストリン $(\mathrm{CD})$ は, 澱粉から CD 合成酵素 (CGTase)の作用により生成するグルコースが 6 個以上 からなる環状オリゴ糖であり, 天然物ホスト化合物であ る。CD は, 有機化学, 無機化学, 分析化学, 生化学, あるいはその境界領域において利用, 研究されているば かりでなく, その包接作用は食料品, 医薬品, 化粧品を はじめ多くの商品に実際に利用されている。

\section{1. はじめに}

CD は, 1891 年に, Villiersにより初めて発見された1)。 1951 年に, Cramer らにより CD による色素の安定化に 関する報告があり ${ }^{2)}$, それ以来 $\mathrm{CD}$ の包接現象に関する 研究および, その包接現象を利用した研究が行われるよ うになり，そして近年いろいろな分野で $\mathrm{CD}$ およびその 誘導体を用いた研究が盛んに行われている。理化学研究 所の掘越らのグループが, 好アルカリ性微生物から $\beta-\mathrm{CD}$ を優先的に, しかも従来と比べて 5 倍以上の収率 で産生するCGTase を単離し，この酵素を用いて日本食 品化工が初めて $\beta$-CD の量産化に成功したのをはじめ, 量産化の技術があいついで日本で確立され安価にCD が 得られるようになった。日本では法的にCD の安全性が 確認されており, 食品添加物をはじめ医薬品, 化粧品な どに幅広く $\mathrm{CD}$ が利用されている ${ }^{4 g \sim \mathrm{k})}$ 。 $\mathrm{CD}$ そのものも

* 東京工業大学工学部生物工学科

* Department of Bioengineering and Bioscience, Faculty of Engineering, Tokyo Institute of Technology
興味あるホスト化合物であるが，CD に修飾を加えるこ とにより，いろいろな機能を付け加えることが出来る。 本総説では，CD を修飾することにより CD の特性がど のように変化し，またどのような機能を CD に導入する ことが可能であるかを中心に紹介する。なお，すでに優 れた成書 ${ }^{3)}$, 総説 ${ }^{4)}$ があるのでそちらも参照されたい。

\section{2. 構造と性質}

$\mathrm{CD}$ は,グルコースが, $\alpha-1,4$ 結合により環状に結合 した環状オリゴ糖であり，特に，グルコース単位が 6 , 7,8 個の物を $\alpha-\mathrm{CD}, \beta-\mathrm{CD}, \gamma-\mathrm{CD}$ と呼んでいる。

$\mathrm{CD}$ は図 1 に示すように円錐台形バケツ型の構造をし ており, 内部が空洞になっている。空洞径の小さい入り 口にC-6 位の一級水酸基が, 大きい入り口にC- 2 およ びC-3 位の二級水酸基が位置している。空洞の内部は, $\mathrm{C}-3, \mathrm{C}-5$ 位の水素およびグリコシド酸素によって構成
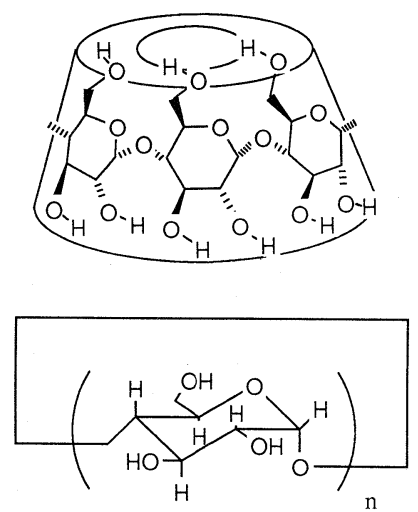

Fig. 1 
Table 1 Physical prorerties of the cyclodextrins.

\begin{tabular}{|l|r|r|r|}
\hline & $\alpha$-CD & $\beta$-CD & $\gamma$-CD \\
\hline Number of glucose residues & 6 & 7 & 8 \\
Molecular weight & 973 & 1,135 & 1,297 \\
Diameter of cavity $(\AA)$ & $5 \sim 6$ & $7 \sim 8$ & $9 \sim 10$ \\
Depth of cavity $(\AA)$ & $7 \sim 8$ & $7 \sim 8$ & $7 \sim 8$ \\
Solubility $\left(\mathrm{g} / 100 \mathrm{ml} \mathrm{H}_{2} \mathrm{O}\right)$ & 14.5 & 1.85 & 23.2 \\
\hline
\end{tabular}

されており，疎水的である。CD の二級水酸基は隣接す るグルコース間で水素結合をしている。 $\mathrm{CD}$ の物理的性 質を表 1 に示す。CD の有機溶媒に対する溶解性は低く, DMF，DMSO などの極性の高い有機溶媒のみに可能で ある。

$\mathrm{CD}$ の安全性が初期のころ問題となっていたが，それ は単離精製の際に用いた有機溶媒が残存していた為であ り，現在の有機溶媒を用いない製法により製造された $\mathrm{CD}$ は，無害であることが法的に確かめられている。な お日本に抏いては局方外医薬品添加物として $\alpha$-CD, $\beta-\mathrm{CD}$ が収載され，食品としては全 $\mathrm{CD}, \mathrm{CD}$ 液が天然添 加物に, 化粧品原料では汎用化粧品原料集に収録されて いる。

\section{3. 未修飾 CD の有機反応に対する作用}

修飾 $\mathrm{CD}$ について紹介する前に未修飾 $\mathrm{CD}$ の有機反応 に対する作用について簡単にふれておく。CD の有機反 応に対する作用は，次の二つに分類される ${ }^{3 a)}$ 。一つは, 非共有結合的作用，即ち， CD の疎水的空洞が特異的な 反応場を提供し基質の反応性を変化させる作用。もう一 つは，共有結合的作用，即ち $\mathrm{CD}$ と基質とが共有結合に より結合し反応中間体を生成して反応が進行し，生成物 を生じる作用である。

3.1. 非共有結合的作用 誘電率の低い溶媒中で非常 に速く進む反応，例えば，フェニルシアノ酢酸アニオン の脱炭酸反応や， $\alpha$-ヒドロキシケトンの $\alpha$-ジケトンへ の酸化反応などは， $\mathrm{CD}$ を添加することにより加速され $3^{5 \sim 6)}$ 。

1 から 3 への分子内アシル基転移反応 (スキーム 1) は,
$\alpha-\mathrm{CD}$ により 6 倍加速されるが， $\beta-\mathrm{CD}$ により 5 倍減速 される。 $\alpha-C D$ の空洞内では 2 のコンホメーションで存 在するのが, $\beta-\mathrm{CD}$ の空洞内では 1 のコンホメーション で存在するのが基質として安定であり，そのために反応 速度に差が生じたのであろう”。

また，CD を添加することにより反応の位置選択性を 変化させることが可能である。アルカリ水溶液中, 銅粉 末存在下フェノールと四塩化炭素とを反応させると，ヒ ドロキシ安息香酸が生成するが，オルト体とパラ体との 比は，ほぼ 1 対 1 である。この反応系に $\beta-\mathrm{CD}$ を添加す るとパラ体が $99 \%$ の選択性で得られる。しかも収率が $8.6 \%$ から $59 \%$ 一向上する ${ }^{8)}$ 。この応は, $\beta-\mathrm{CD}$, フェ ノール，抽び四塩化炭素から生じるトリクロロメチル カチオンより構成される三成分分子錯体を経由して進行 すると考えられている(スキーム 2)。アルカリ水溶液中

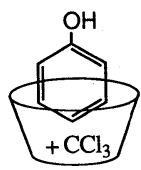

4<smiles>O=C(O)c1ccc(O)cc1</smiles>

5
Scheme 2

では, フェノールは解離しておりスキーム 2 に示す方向 からしかフェノールは $\beta-\mathrm{CD}$ に包接されない。そのため に，パラ体が優先的に生成する。また，四塩化炭素の代 わりにクロロホルムを用いると 4-ヒドロキシベンズア ルデヒドが，ほぼ $100 \%$ の選択性で得られる ${ }^{9)} 。$

水素化ホウ素ナトリウムを用いる還元反応において

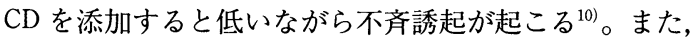
Diels-Alder 反応におけるエンド選択性が CD の添加に より高まるなど ${ }^{11)}, \mathrm{CD}$ による様々な添加効果が報告さ れている。そして，相間移動触媒として Wacker 反応へ 利用した例など12)，いろいろな利用例が報告されてい る ${ }^{13)}$ 。

3.2. 共有結合的作用 $\mathrm{CD}$ の二級水酸基はアルカリ 水溶液中でアルコキシアニオンになり, 包接したエステ<smiles>CCCOc1ccc([N+](=O)[O-])cc1CO</smiles>

1<smiles>C=C=C=C</smiles>

2<smiles>CC(C)(C)OCc1cc([N+](=O)[O-])ccc1O</smiles>

3

Scheme 1 
ルを求核攻撃により分解する。この反応は, 天然酵素 $\alpha$-キモトリプシンによる反応と反応特性が類似してい ることから,酵素モデルとして詳細に検討されている ${ }^{14)} 。$ 反応は，スキーム 3 に示すように進行する。

$$
\mathrm{CD}+\mathrm{S} \underset{\text { Scheme } 3}{\mathrm{CD} \cdot \mathrm{S}} \underset{\mathrm{CD}^{\prime}+\mathrm{P}_{1} \longrightarrow \mathrm{CD}+\mathrm{P}_{2}}{\longrightarrow}
$$

ここで $\mathrm{S}$ は基質, $\mathrm{CD} \cdot \mathrm{S}$ は包接複合体, $\mathrm{CD}^{\prime}$ はアシル化 $\mathrm{CD}, \mathrm{P}_{1}$ はアルコール， $\mathrm{P}_{2}$ は酸である。この反応は， $\mathrm{CD}^{\prime}$ の脱アシル化反応が極めて遅く, ターンオーバーは しない。従って, 反応は $[\mathrm{S}] \ll[\mathrm{CD}]$ の条件で行われ, 種々 のエステルを基質として速度論的に検討がなされ，基質 特異性があることが知られている。CDによる加速効果 の基質特異性は, Hammett の置換基定数と相関関係が 見られないことから，電子的要因によるものではない。 むしろ, 基質と $\mathrm{CD}$ との幾何学的要因に基づいている。 例えば, 酢酸ニトロフェニルの分解反応における加速効 果が, メ夕体の方がパラ体よりも約 90 倍大きいのは, カルボニル基とアルコキシアニオンとの距離の違いに よって理解できる。

\section{4. 修飾シクロデキストリン}

$\mathrm{CD}$ を化学的に修飾することにより $\mathrm{CD}$ に新たな機能 を持たせることが可能であり, CD の包接能を変化させ たり，CD を基本骨格として人工酵素を構築したりする ことが出来る。

4.1. スルホニル化 $\mathrm{CD}$ に官能基を導入する場合, まず CD をスルホニル化するのが一般的であり, 条件を 適当に選ぶことにより, 多数ある水酸基のうち一個だけ を位置選択的にスルホニル化することが可能である。ピ リジン中パラトルエンスルホニルクロリド $(\mathrm{TsCl})$ と反 応させることにより一級水酸基をトシル化することが出 来る ${ }^{15)}$ 。二級水酸基を選択的にスルホニル化する為には, 工夫が必要である。DMF とアルカリ緩衝液の混合溶媒 中メタニトロフェニルトシレートを用いてトシル化を行 うと C-2 位の水酸基が選択的にトシル化される ${ }^{16)}$ 。また, $\mathrm{Bu}_{2} \mathrm{SnO}$ を用いても $\mathrm{C}-2$ 位の水酸基をスルホニル化する ことができる ${ }^{17)}$ 。 $\mathrm{pH}$ を 13 以上に保ったアルカリ水溶液 中でトシル化を行うと $\beta-\mathrm{CD}$ は一級水酸基 (C-6 位)が卜 シル化される。一方， $\alpha-\mathrm{CD}$ は， C- 2 位の水酸基がトシ ル化される ${ }^{18)}$ 。しかし, 反応の進行に伴い $\mathrm{pH}$ がアルカ リ性から酸性に変化する条件でスルホニル化反応を行う と, C-2 位の水酸基がスルホニル化された修飾体のほか に, C-3 位あるいは C-6 位の水酸基がスルホニル化さ れた修飾体も同時に得られてくる ${ }^{19)}$ 。また2-ナフタレ ンスルホニルクロリドを用いてアルカリ性の $30 \%$ アセ
トニトリル水溶液中で $\beta-\mathrm{CD}$ をスルホニル化すると, C-3 位の水酸基がスルホニル化される20)。

C-6 位の水酸基二個を位置選択的にスルホニル化する 方法としてキャップ試薬が開発されている ${ }^{21)} 。 \alpha-\mathrm{CD} の$ グルコース単位を図 2 に示すように A, B ……とすると, 二置換体には, $\mathrm{AB}$ 体, $\mathrm{AC}$ 体, $\mathrm{AD}$ 体の三種類の位置異

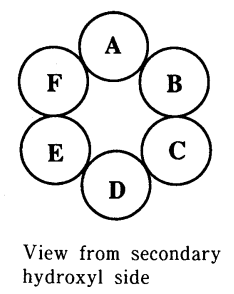

Fig. 2

性体が存在するが, キャップ試薬を用いるといずれかが 主に生成する。また， TsCl やメシチレンクロリドを用 いて $\mathrm{AB}$ 体, $\mathrm{AC}$ 体, $\mathrm{AD}$ 体の混合物を合成した後に逆 相カラムクロマトグラフにより分離精製する方法も報告 されており, 単離した修飾体の構造は Taka amylase 分 解した後に, NMR やFABMS などにより決定されてい る22)。そしてスルホニル化郕を使い分けることにより C-2 位あるいは C-3 位の二置換体の混合物を合成する ことができ分離精製されている。さらに三置換体以上の 修飾体も同様な方法により合成されている ${ }^{23)}$ 。

4.2. 人工酵素さて, $\mathrm{CD}$ に官能基を導入するとど のような特性を CD に導入することが可能であろうか。 まず，人工酵素について紹介する。

4.2.1. $\alpha$-キモトリプシンモデル 天然加水分解酵素 $\alpha$ キモトリプシンの反応中心は, Ser-195 の水酸基, His-57 のイミダゾール基, Asp-102のカルボキシル基 である。そこで, $\mathrm{CD}$ の加水分解反応に対する加速効果 を改善するために, CD をヒスタミンで修飾することが 行われている ${ }^{24)}$. 未修飾の CD は, 高アルカリ条件下で

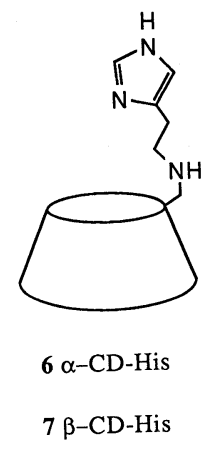


ないと活性がなく，ターンオーバーもしない。CD をヒ スタミンで修飾することにより中性条件下で高い活性を 示すようになり，しかもターンオーバーもするようにな る。また, 酢酸ニトロフェニルの位置異性体に対する反 応の位置選択性は未修飾の $\mathrm{CD}$ は $\alpha, \beta-\mathrm{CD}$ いずれもが メ夕選択性である ${ }^{14)}$ 。一方， $\alpha$-CD をヒス夕ミンで修飾 した修飾体 (6) はメ夕選択性であるが， $\beta$-CD をヒス夕 ミンで修飾した修飾体 ( 7 ) はパラ選択性であり，修飾体 は空洞の大きさの違いにより選択性が異なる ${ }^{24)} 。$

また， $\gamma$-CD にイミダゾール基を導入した修飾体が合

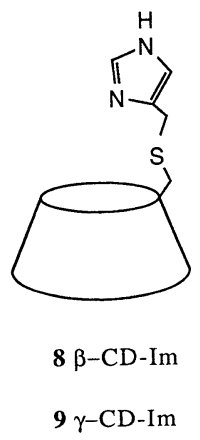

成されている ${ }^{25)}$ 。 $\gamma$-CD は大きな空洞を有する為に, $\alpha$, および $\beta-\mathrm{CD}$ とは異なった挙動を示す。反応系中に $1-$ ナフタレンアセテートを添加すると， 8 による加水分解 反応は阻害され反応速度が減少するが，9の場合は逆に 増大する。これは, 添加剤が前者の場合基質の包接を阻 害するように㗢いたのに対して，後者の場合，図 3 に示

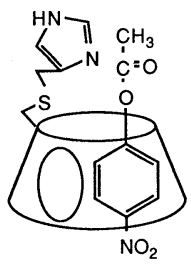

Fig. 3

すように大きな $\gamma-\mathrm{CD}$ の空洞を狭くするように働き，反 応を進行しやすくしている。この効果はスペーサー効果 と呼ばれており，他の $\gamma-\mathrm{CD}$ 修飾体にも見られる現象で ある。また，8による加水分解反応は進行に伴い生成物 阻害を受け反応速度が減少する。しかし，9の場合反応 の進行に伴い反応速度は減少しない。これは， $\gamma-\mathrm{CD} の$ 空洞が阻害効果が無視出来るぐらい大きいことによるも のであり， $\gamma$-CD 修飾体の特徴の一つである。 $\alpha$-キモトリプシンの反応中心をすべてもった人工酵 素 (10) が， $\beta-\mathrm{CD}$ の二級水酸基の修飾によって達成され

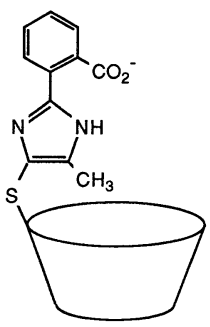

10

ている ${ }^{26)}$ 。この人工酵素の触媒活性は, 天然酵素と同程 度である。 $\alpha$-キモトリプシンは $45^{\circ} \mathrm{C}$ 付近で最大活性を 示すが, $55^{\circ} \mathrm{C}$ 近で沈殿を生じ失活してしまう。一方, この人工酵素は $80^{\circ} \mathrm{C}$ でも安定で活性を保持しており, $\mathrm{CD}$ を修飾することにより天然酵素よりも優れた人工酵 素を構築できる可能性を示している26b)。

$\mathrm{CD}$ の C-2，C-6 位の水酸基をすべてメチル化したジ メチルシクロデキストリン $(\mathrm{DMCD})$ はユニークな特性を 持っている。 $\beta-\mathrm{CD}$ がほとんど有機溶媒に不溶なのに対 して， $\beta$-DMCD は各種有機溶媒に可溶である。また, $\beta-\mathrm{CD}$ が, 水 $100 \mathrm{ml}$ に $1.8 \mathrm{~g}$ しか溶解しないのに対して, $\beta-\mathrm{DMCD}$ は $55 \mathrm{~g}$ も溶解する。さらに，水に対する溶解 度の温度依存性は, $\beta-\mathrm{CD}$ と $\beta$ - DMCD とでは正反対で ある(図4)。

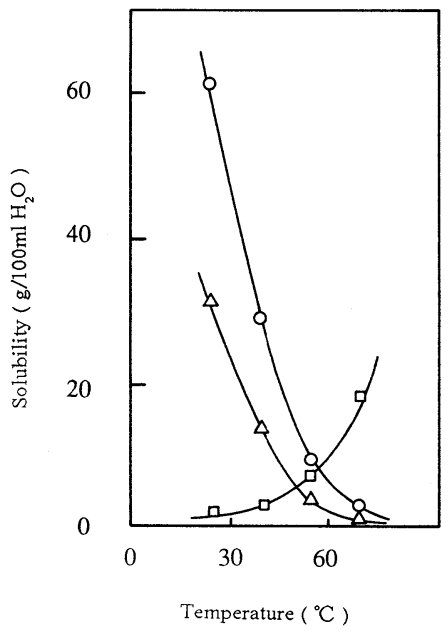

Fig. 4 Temperature dependence of solubilities of $\beta$ cyclodextrin, dimethyl- $\beta$-cyclodextrin and trimethyl- $\beta$-cyclodextrin ;

$\square: \beta$-cyclodextrin, $\bigcirc$ : dimethyl- $\beta$-cyclodextrin $\triangle:$ trimethyl- $\beta$-cyclodextrin 
このユニークな性質に着目し $\beta$-DMCD を用いた人工 加水分解酵素の構築が行われている ${ }^{27)} \beta \beta$-DMCD の C -3 位の水酸基は隣接するグルコース残基の $\mathrm{MeO}$ 基との間 で水素結合をしており反応性に之しくこれまでの方法で は修飾することが出来ない。そこでまず $\mathrm{NaH} に よ り$ 活 性化した後に，エーテル化により官能基を導入すること によって初めて修飾に成功している。得られた修飾体 （11）は, 加水分解反応を非常に大きく加速する。例えば,

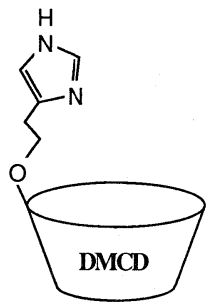

11

11 は酢酸パラニトロフェニルの加水分解反応を 921 倍 も加速する能力を持っている。天然酵素 $\alpha$-キモトリプ シンの至適 $\mathrm{pH}$ である 8.0 付近において，この修飾体の $k_{\text {cat }}$ は $\alpha$-キモトリプシンの 2 倍以上である。また $\beta-\mathrm{CD}$ の修飾体と比べて $k_{c a t}, \quad k_{c a t} / K_{m}$ がともに7-11 倍以上 の值を示している(表 2)。な押， $k_{\text {cat }}$ は包接複合体内に おける反応の一次速度定数であり， $k_{c a t} / K_{m}$ はオーバー オールの反応速度を反映する速度定数である。

4.2.2. NADH 補酵素モデル 1,4-ジヒドロニコチンア ミドを CD に導入することにより $\mathrm{NADH}$ 補酵素モデル が合成されている ${ }^{28)}$ 。NADH 補酵素モデルとして一般に 用いられている $N$-アルキル-1,4-ジヒドロニコチンアミ ドは，水と反応してしまう為に，水中での均一反応に用 いることが出来ない。一方, 修飾体 (12) は, 水和反応を 受けにくく水中で安定であり, しかも, ニンヒドリンを $\mathrm{NADH}$ と比べて 50 倍速く還元することが出来る。

4.2.3.リボヌクレアーゼモデル リボヌクレアーゼは

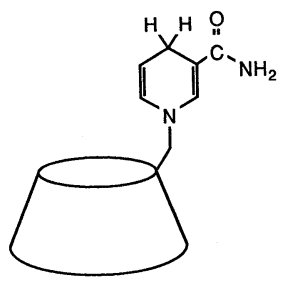

12

RNA のホスホジエステル結合の開裂反応を触媒する酵 素である。反応は二段階で進行し，まずRNAの 2 位水 酸基の分子内攻撃により環状リン酸エステルが生じ，そ の後，この環状リン酸エステルが位置選択的に開裂し反 応は終了する $($ スキーム 4)。このリボヌクレアーゼの第 二段階目の反応のモデル化 (スキーム5)の試みとして, $\beta-\mathrm{CD}$ の一級水酸基側に二個のイミダゾール基を導入し た修飾体が合成されている ${ }^{29)}$ 。この修飾体による加水分 解反応の速度を $\mathrm{pH}$ に対してプロットすると, $\mathrm{pH} 7$ 付近 で極大值を持つ Bell 型の曲線が得られる。このことは,

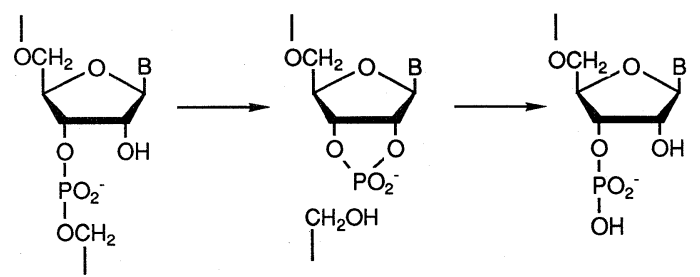

Scheme 4<smiles>CC(C)(C)c1ccc2c(c1)OP(=O)([O-])O2</smiles>

Scheme 5

Table 2 Kinetic parameters for the hydrolysis of PNPA at $\mathrm{pH} 8$.

\begin{tabular}{|c|c|c|c|c|}
\hline \multirow{2}{*}{ Enzyme } & $k_{\text {cat }}$ & $K_{\mathrm{m}}$ & $k_{\text {cat }} / K_{\mathrm{m}}$ & $k_{\text {cat }} / k_{\text {un }}$ \\
\cline { 2 - 5 } & $10^{-3} \mathrm{~s}^{-1}$ & $10^{-3} \mathrm{M}$ & $\mathrm{M}^{-1} \mathrm{~s}^{-1}$ & - \\
\hline 6 & 0.50 & 2.81 & 0.18 & 17 \\
7 & 2.32 & 2.02 & 1.15 & 80 \\
11 & 26.7 & 2.90 & 9.20 & 921 \\
$\alpha$-Chymotrypsin & 11 & 0.04 & 275 & 379 \\
\hline
\end{tabular}


$\mathrm{CD}$ に導入された二個のイミダゾール基のうち一方が一 般塩基触媒として働き, 他方が一般酸触媒として働いて いることを示しているものであり，この修飾体が天然酵 素と同じ触媒機構で加水分解反応をしていることを示し ている。また, 反応は位置選択的に進行し，イミダゾー ル基と $\mathrm{CD}$ との距離の違いによりリン酸結合の開裂位置 が異なってくる。これは, 図 5 に示すように基質とイミ ダゾール基との位置関係の違いに基づくものである。

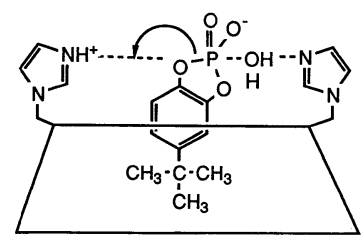

13

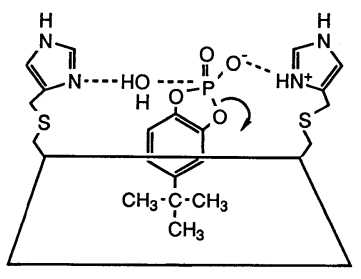

14

Fig. 5

4.2.4. アミノ基転移酵素モデル アミノ基転移酵素の モデル化合物として，ピリドキサミン基を有する $\beta-\mathrm{CD}$ 修飾体 (15) が合成されている30)。ピルビン酸(17 a)から アラニン (18 a)，およびインドールピルビン酸 $(17 \mathrm{~b})$ か らトリプトファン $(18 b)$ への反応をピリドキサミン (19) 存在下で行うと, 両者の生成速度に差は見られない。し

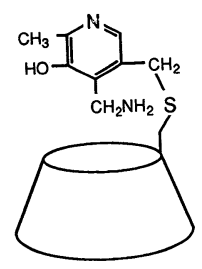

15

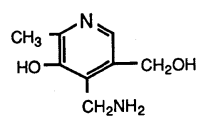

19

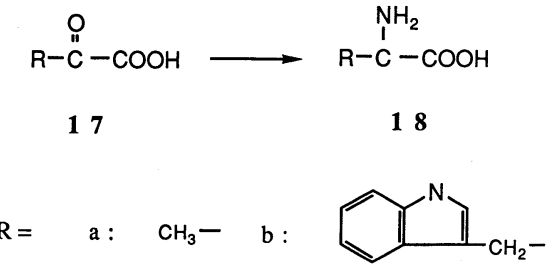

Scheme 6

かし，15存在下，トリプトファンの生成とアラニンの 生成とを競争させると, 前者が, 後者に比べて 50 倍速 く進行する ${ }^{31 b)}$ 。これは, インドール環が選択的に包接 され，反応が加速されたことを示している。また，15は， 19 と比べてフェニルアラニンの合成を 15 倍, トリプト ファンの合成を 12 倍加速する。

$\beta-\mathrm{CD}$ の二級水酸基側にピリドキサミン基を導入した 修飾体 (16) も合成されている ${ }^{31)}$ 。この修飾体は，ケト酸

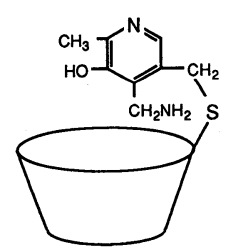

16

から，フェニルアラニンおよびトリプトファンの合成を 19 と比べて 20 倍加速する。興味あることに，15と 16 とで生成物の立体選択性に違いが見られる。15を用い ると,トリプトファン生成の際 $2: 1$, フェニルアラニ ン生成の際 $5: 1$ の割合で L 体を過剩に生成する。一方, 16 を用いると,トリプトファン生成の際 $1.8: 1$ の割合 でD体を過剩に生成するがフェニルアラニン生成の際選 択性はなく，修飾位置の違いによりエナンチ才選択性に 差がみられる。

このアミノ基転移反応における不斉誘起は, シッフ塩 基がプロトン化される際におこる。従って，シッフ塩基 の一方向からしかプロトン化が起こらないように工夫す れば不斉収率が上がるはずである。このような発想の基 に，20のような二点修飾体が合成されている ${ }^{32)}$ 。隣接 するグルコース単位に二種類の官能基を導入する場合, $\mathrm{AB}$ 体, $\mathrm{BA}$ 体の二種類の位置異性体が生成するが, 目 的とする $\mathrm{AB}$ 体 (20) は，カラムクロマトグラフィーによ り単離精製された。20を用いると, フェニルピルビン 酸から 96 \% e.e.の選択率で L 体のフェニルアラニンが 得られる。同様に, 90 \% e.e.の選択率で L 体のトリプ 


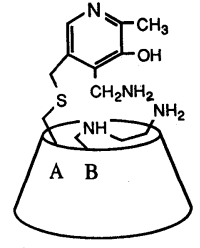

20

トファンが得られる。このような高い選択率を与える機 構は, 図6に示すように, 反応中間体として生成するプ ロキラルなアゾメチン基の平面の一方がエチレンジアミ ン基の $\omega$-アミノ基により固定されその状態でプロトン 化が起こるためだと考えられている。

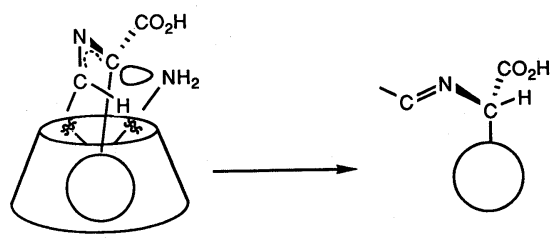

Fig. 6

4.3. 分子認識 $\mathrm{CD}$ を修飾することにより分子識別 能を高めることが可能である。 $\beta-\mathrm{CD}$ の C-3 位をアセチ ルアミノ化した修飾体 (21) を添加すると, アミノ酸の $\alpha$-プロトンの NMR におけるケミカルシフトが変化する

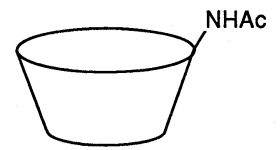

21
が，D体と L 体とではその変化量が異り，キラルシフト 試薬としての機能をこの修飾体は有している $(\text { 表 } 3)^{33)}$ 。 この修飾体による変化量は未修飾の $\beta-\mathrm{CD}$ や -6 位を 修飾した修飾体よりも大きく，これは C-3 位を修飾す る際にグルコース環の構造が变化し空洞が歪んだことに よるものであろう。

4.4. 包接能の制御 CD をナフタレンやアントラセ ンで修飾することにより, 包接挙動を変化させることが 可能である ${ }^{34 ~ 36) 。 ~} \gamma$-CD は空洞が大きいために安全な 1 : 1 コンプレックスを形成することが出来ず, $1: 2$ コン プレックスを形成する。ところが， $\gamma-\mathrm{CD}$ にナフタレン 環を導入すると, ナフタレン環が $\gamma$-CD の空洞を狭くす るスペーサーとして機能し, ゲストと安定な $1: 1$ コン プレックスを形成出来るようになる $(\text { 図 7 })^{34)}$ 。

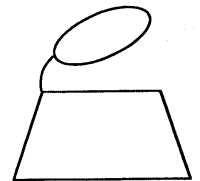

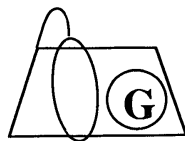

Fig. 7
$\gamma$-CD の AE の位置に導入された二個のナフタレン環 は, Induced-fit 型の機構により包接能を制御すること が出来る ${ }^{35)}$ 。ゲスト不在下では二個のナフタレン環は空

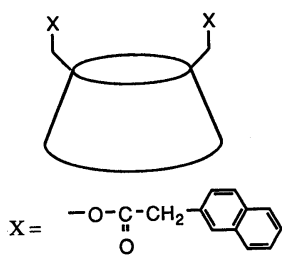

22

Table 3 Chemical shifts of methine proton of amino acids in the presence of host $\left(D_{2} \mathrm{O}, 360 \mathrm{MHz}\right)$.

\begin{tabular}{|l|c|c|c|c|c|c|}
\hline & Guest & \multicolumn{2}{|c|}{ Mandelic acid } & \multicolumn{2}{|c|}{ Methyl mandelate } & \multicolumn{2}{|c|}{$\begin{array}{c}\text { N-Acetyl- } \alpha \text { - } \\
\text { phenylglycine } \\
\text { Host }\end{array}$} & L & D & L & D & \multicolumn{2}{c|}{ L } \\
\hline none & \multicolumn{2}{|c|}{5.30} & \multicolumn{2}{|c|}{5.35} & \multicolumn{2}{|c|}{5.42} \\
\hline$\beta$-CD & 5.202 & 5.198 & \multicolumn{2}{|c|}{5.32} & 5.465 & 5.456 \\
\hline $\begin{array}{l}\text { 6-acethylamino- } \\
\text { 6-deoxy- } \beta \text {-CD }\end{array}$ & 5.202 & 5.197 & \multicolumn{2}{|c|}{5.29} & 5.461 & 5.454 \\
\hline $\begin{array}{l}\text { 3-acethylamino- } \\
\text { 3-deoxy- } \beta \text {-CD }\end{array}$ & 5.22 & 5.20 & 5.34 & 5.32 & 5.52 & 5.45 \\
\hline
\end{tabular}


洞内で会合していることが円偏光二色性スペクトルによ り調べられている。未修飾の $\gamma-\mathrm{CD}$ に二分子が包接され るシクロヘキサノールと修飾体 (22) とは安定な $1: 1$ コ ンプレックスを形成する。エキシマー蛍光がシクロヘキ サノールの添加によりあまり変化しないことから，この ナフタレン環はスペーサー機構ではなく，二個のナフタ レン環が同時に動くInduced-fit 型の機構(図 8)により 包接能を制御していると考えられている。また， $\beta-\mathrm{CD}$ をアントラセン環で一点修飾すると, 図 9 に示すような Induced-fit 型の制御機構を持ったフレキシブルな キャップを持たせることが出来, 包接能を高めることが
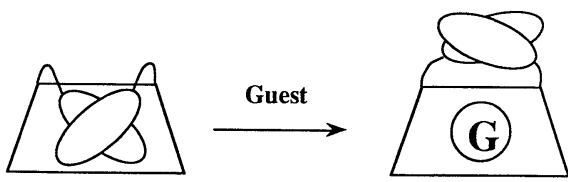

Fig. 8
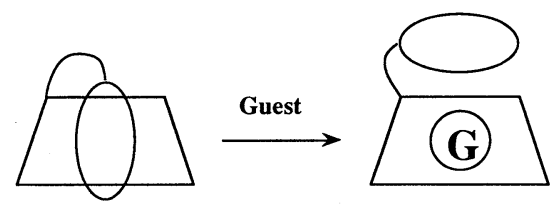

Fig. 9

出来る ${ }^{36)}$ 。

$\beta-\mathrm{CD}$ をアゾベンゼンでキャップすることにより包接 能を光によって可逆的に制御することが出来る。アゾ基 は，紫外光照射によりトランス体からシス体に異性化す る。また，シス体は熱または可視光照射によりトランス 体へ戻る。23のアゾ基がトランス体の時, 空洞は浅く なり，シス体の時，逆に疎水的空洞は拡大され，二分子 を包接出来るようになる(図 10) ${ }^{37)}$ 。

$\mathrm{CD}$ の一級水酸基をすべて 2-ナフタレンスルホニル化

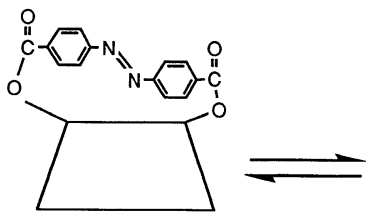

23 a

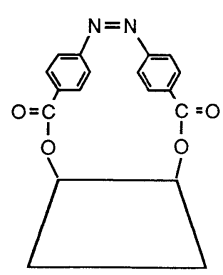

23 b
Fig. 10
した修飾体は，水層から有機層への金属イオンの抽出能 を有している ${ }^{38)}$ 。この場合，二級水酸基をすべてアセチ ル化すると，その抽出能力は $\mathrm{CD}$ 環の大きさにより異な る。 $\alpha^{-}$, および $\beta-\mathrm{CD}$ 修飾体がほぼ $100 \%$ の抽出能力を 有しているのに対して， $\gamma$-CD 修飾体の抽出能力は 25 \% 以下である。一方，二級水酸基を修飾しないと，環 の大きさによる差はほとんど見られない。これらの抽出 能力は, ジベンゾ-18-クラウン -6 と比べても非常に大 きい。 $\mathrm{CD}$ の水酸基をすべてメタンスルホニル化した修 飾体がほとんど抽出能力がないことから，2-ナフタレン 環が金属イオンの抽出に重要な働きをしていることがわ かる。また，ジエチレントリアミンやトリエチレンテト ラミンで修飾したり，アンモニウム基やピリジニウム基 を導入すると，イオン的相互作用により金属やイオン的 ゲストと複合体を形成する能力が高まる ${ }^{39)}$ 。

\section{5. 包接の駆動力と包接複合体の構造}

5.1. 包接の駆動力 ところで, $\mathrm{CD}$ はどのような駆 動力によってゲストを包接するのだろうか?これはいま だに十分に解明されていない命題である。ゲストを包接 する際，疎水的相互作用が重要であることは，水中で最 も包接複合体を形成しやすいことからわかる。しかし， 包接に伴う熱力学的パラメーターを求めてみると, $\Delta \mathrm{S}^{\circ}$, $\Delta \mathrm{H}^{\circ}$ が共にマイナスの場合が多い。酵素や抗体に見ら れるように疎水的相互作用とは，水分子の自由度の増大 に伴う正のエントロピー変化 $\left(\Delta S^{\circ}>0\right)$ が駆動力となっ て起こる相互作用である。従って, 包接の駆動力として 疎水的相互作用以外の作用が存在することになる。そし て, 複数の相互作用が足し合わさった結果 $\Delta \mathrm{S}^{\circ}, \Delta \mathrm{H}^{\circ}$ が 共にマイナスになったのであろう。CD の包接に関与し ていると考えられている相互作用として次のようなもの がある ${ }^{3,40)}$ 。1) 疎水的相互作用, 2) van der Waals 相互作 用，3）ゲスト分子と CD の水酸基との間の水素結合，4） $\mathrm{CD}$ の空洞内に存在する高エネルギー水がゲスト分子の 包接に伴い放出されることによる相互作用, 5)CD のコ ンフォメーションの歪みがゲスト分子の包接により緩和 されることによる相互作用。そして，これらの相互作用 が協同的に作用することにより包接体が安定化される。 構造活性相関を用いた検討により，駆動力として疎水的 因子と立体的因子が特に重要であり，ゲストの種類に よっては，電子的因子などがさらに関与しているという 回帰式が得られている ${ }^{41)}$ 。また, ゲストが包接される際 の熱力学パラメーターが数多くのゲストについて求めら れている ${ }^{42)}$ 。さらに, CD の空洞の静電ポテンシャルが 計算により求められており， $\mathrm{CD}$ の分子には，対称軸に 
沿って大きな電荷分極が存在するという結論が報告され ており, 包接の駆動力の解明に役立つことが期待され る

\section{2. 包接複合体の構造 ゲスト化合物が CD に包接} されているかどうかは, 各種の分光学的方法などにより 調べることが出来る。良質な単結晶が得られた包接複合 体については, X 線結晶解析により構造が決定されてい $ろ^{44)}$ 。CD の包接複合体の場合, 結晶の構造と溶液中で の構造が必ずしも等しくない。CD の有機反応に対する 効果を理解するうえで溶液中での包接複合体の構造を明 らかにする必要があるが, NMR や円偏光二色性スペク トルにより情報を得ることができる ${ }^{45.46)}$ 。しかし, 詳細 な構造はまだ解明されておらず今後の研究を待たなけれ ばならない。特に，修飾 CD に関しては，まだほとんど 分かっていない。なお, ゲスト分子は, CDの空洞内に おいてもかなり自由に回転運動をしているようである。

\section{6. おわりに}

日本における CD の生産量は, $\mathrm{CD}$ 換算年間 700 トン 程度であり，毎年約 $30 \%$ の割合で伸びている。米国， 欧州に挄いても, 日本からの技術導入による量産化計画 が進行しており，CDの市場はますます拡大し， CD が 我々の生活にますます密着した化合物になっていくであ ろう。

今回は, 紹介しなかったが, CD を結合させた HPLC カラムがすでに市販されており異性体分離に威力を発揮 している ${ }^{47)}$ 。また, DMCD が百日咳菌用培地に有効な添 加剂であるという報告もあり，ますます CD の応用分野 が広がっていくであろう。

一方， $\mathrm{CD}$ を高次に修飾することにより，CD は単な る疎水的空洞から, 高度な分子識別能, 高活性な触媒能 などを有する高機能性分子素子となることが期待され る。その為には, ゲスト分子の CD 空洞内での動的挙動 の解明, 包接能を自由に制御する方法の確立, そして任 意の位置に官能基を導入することができる修飾法の開発 などが望まれる。

(平成元年 1 月 20 日受理)

\section{文献}

1) A. Villiers, Compt. Rend., 112, 536 (1891)

2) F. Cramer, Chem. Ber., 84, 851 (1951)

3a) M.L. Bender, M. Komiyama, “シクロデキストリ ンの化学” (平井英史, 小宮山真訳), 学会出版セン 夕ー (1979)

b) J. Szejtli, "Cyclodextrins and Their Inclusion Complexes”, Akademiai Kiado, Budapest (1982) c) D. Duchene, ed., "Cyclodextrins and Their Industrial Uses”, Sante, Paris (1987)

d)J. Szejtli, "Cyclodextrin Technology", Kluwer Academic Publishers, Dordrecht (1988)

4a) W. Saenger, Angew. Chem . Int . Ed . Engl . , 19, 344 (1980)

b) A.P. Croft, R.A. Bartsch, Tetrahedron, 39, 1417 (1983)

c)I. Tabushi, Acc. Chem. Res., 15, 66 (1982)

d) 戸田不二緒, 池田宰, フレグランスジャーナル, 63, 90 (1983)

e)上野昭彦, 長 哲郎, 化学工業, 1984, 1055

f)上野昭彦, “シクロデキストリン”, 戸田不二緒編, “人工酵素・生体膜デザイン”, CMC (1985) p.53

g) 御船 昭, 島 淳之, 有合化, 35, 116 (1977)

h) 上釜兼人, 平山文俊, 科学と工業, 59, 443 (1985)

i) 長友新治, 化学経済, 1985 ( 8), 10

j) 原 耕三, 橋本 仁, 澱粉化学, 33, 152 (1986)

k) 中村信之, バイオインダストリー, 2, 261 (1985)

1) H. Bender, Advances in Biotechnological Processes, 6,31

5) T.S. Straub, M.L. Bender, J. Am. Chem. Soc., 94, 8875 (1972)

6) F. Cramer, Chem. Ber., 86, 1576 (1953)

7a)D.W. Griffiths, M.L. Bender, J. Am . Chem. Soc., 95, 1679 (1973)

b) D.W. Griffiths, M.L. Bender, Bioorg. Chem ., 4, 84 (1975)

8) M. Komiyama, H. Hirai, J. Am. Chem. Soc., 106, 174 (1984)

9) M. Komiyama, H. Hirai, ibid., 105, 2018 (1983)

10) R. Fornasier, F. Reniero, P. Scrimin, U. Tonellato, J. Org. Chem., 50, 3209 (1985)

11a) R. Breslow, T. Guo, J. Am . Chem . Soc . , 110, 5613 (1988)

b) H-J. Schneider, N.K. Sangwan, Ang. Chem. Int . Ed. Engl., 26, 896 (1987)

12a) H.A. Zahalka, K. Januszkiewicz, H. Alper, J. Mol. Cat., 35, 249 (1986)

b) A. Harada, Y. Hu, S. Takahashi, Chem. Lett., 1986, 2083

13a) R. Fornasier, V. Lucchini, P. Scrimin, U. Tonellato, J. Org. Chem., 51, 1769 (1986)

b) V. Ramamurthy, D.F. Eaton, Acc. Chem. Res., 21, 300 (1988)

c) M. Komiyama, Chem. Lett., 1988, 1121

d) A.V. Veglia, R.H. De Rossi, J. Org . Chem ., 53, 5281 (1988)

e) O.S. Tee, J.M. Bennett, J. Am . Chem . Soc ., 110, 269 (1988)

14a)R.L. VanEtten, J.F. Sebastian, G.A. Clowes, M.L. Bender, J. Am. Chem. Soc . , 89, 3242 (1967)

b) R.L. VanEtten, G.A. Clowes, J.F. Sebastian, 
M.L. Bender, ibid., 89, 3253 (1967)

c) M. Komiyama, M.L. Bender, ibid., 100, 4576 (1978)

15) L.D. Melton, K.N. Slessor, Carbohydr. Res ., 18, 29 (1971)

16) A. Ueno, R. Breslow, Tetrahedron Lett., 34, 3451 (1982)

17) T. Murakami, K. Harata, S. Morimoto, ibid ., 28, 321 (1987)

18) K. Takahashi, K. Hattori, F. Toda, ibid., 25, 3331 (1984)

19a) K. Fujita, S. Nagamura, T. Imoto, T. Tahara, T. Koga, J. Am. Chem. Soc., 107, 3233 (1985)

b) K. Fujita, T. Tahara, S. Nagamura, T. Imoto, T. Koga, J. Org. Chem., 52, 636 (1987)

20) K. Fujita, T. Tahara, T. Imoto, T. Koga, J. Am. Chem. Soc., 108, 2030 (1986)

21a)I. Tabushi, K. Shimokawa, N. Shimizu, H. Shirakata, K. Fujita, ibid., 98, 7855 (1976)

b) 西谷孝子, 田伏岩夫, 日化誌, 1987, 265

c)F. Moriwaki, H. Kaneko, A. Ueno, T. Osa, F. Hamada, K. Murai, Bull. Chem. Soc.Jpn., 60, 3619 (1987)

22a) K. Fujita, A. Matsunaga, T. Imoto, J. Am. Chem . Soc., 106, 5740 (1984)

b) K. Fujita, A. Matsunaga, T. Imoto, Tetrahedron Lett . , 25, 5533 (1984)

c) K. Fujita, H. Yamamura, T. Imoto, T. Fujioka, K. Mihashi, J. Org. Chem., 53, 1943 (1988)

23) K. Fujita, H. Yamamura, A. Matsunaga, T. Imoto, K. Mihashi, T. Fujioka, J. Am. Chem. Soc., 108, 4509 (1986)

24a) T. Ikeda, R. Kojin, C-J. Yoon, H. Ikeda, M. Iijima, K. Hattori, F. Toda, J. Inclusion Phenom ., 2, 669 (1984)

b) T. Ikeda, R. Kojin, C-J. Yoon, H. Ikeda, M. Iijima, F. Toda, ibid., 5, 93 (1987)

c) R. Kojin, Y. To, H. Ikeda, C-J. Yoon, M. Iijima, T. Ikeda, F. Toda, ibid., in press

25) A. Ueno, F. Moriwaki, T. Osa, T. Ikeda, F. Toda, K. Hattori, Bull. Chem. Soc. Jpn ., 59, 3109 (1986)

26a) V.T. D'Souza, K. Hanabusa, T. O'Leary, R.C. Gadwood, M.L. Bender, Biochem. Biophys. Res. Commun., 129, 727 (1985)

b) V.T. D’Souza, M.L. Bender, Acc. Chem. Res., 20, 146 (1987)

27a) H. Ikeda, R. Kojin, C-J. Yoon, T. Ikeda, F. Toda, Chem. Lett., 1987, 1495

b) H. Ikeda, R. Kojin, C-J. Yoon, T. Ikeda, F. Toda, Tetrahedron Lett., 29, 311 (1988)

c) H. Ikeda, R. Kojin, C-J. Yoon, T. Ikeda, F. Toda, J. Inclusion Phenom., in press
28a)C-J. Yoon, H. Ikeda, R. Kojin, T. Ikeda, F. Toda, J. Chem. Soc., Chem. Commun., 1986, 1080

b) C-J. Yoon, H. Ikeda, R. Kojin, T. Ikeda, F. Toda, J. Inclusion Phenom. , 5, 85 (1987)

29a) R. Breslow, J.B. Doherty, G. Guillot, C. Lipsey, J. Am. Chem. Soc., 100, 3227 (1978)

b) R. Breslow, P. Bovy, C. Lipsey, ibid . , 102, 2115 (1980)

30) R. Breslow, M. Hammond, M. Lauer, ibid., 102, 421 (1980)

31a)R. Breslow, A.W . Czarnik, ibid., 105, 1390 (1983)

b) R. Breslow, A.W. Czarnik, M. Lauer, R. Leppkes, J. Winkler, S. Zimmerman, ibid ., 108, 1969 (1986)

32) I. Tabushi, Y. Kuroda, M. Yamada, H. Higashimura, ibid., 107, 5545 (1985)

33) T. Murakami, K. Harata, S. Morimoto, Chem. Lett. , 1988, 553

34) A. Ueno, Y. Tomita, T. Osa, J. Chem. Soc., Chem. Commun., 1983, 976

35) A. Ueno, F. Moriwaki, T. Osa, F. Hamada, K. Murai, Bull. Chem. Soc. Jpn., 59, 465 (1986)

36) A. Ueno, F. Moriwaki, T. Osa, F. Hamada, K. Murai, J. Am. Chem. Soc., 110, 4323 (1988)

37a) A. Ueno, H. Yoshimura, R. Saka, T. Osa, ibid ., 101, 2779 (1979)

b) A. Ueno, Y. Tomita, T. Osa, Tetrahedron Lett., 24, 5245 (1983)

38) A. Ueno, H. Sasaki, M. Fukushima, S. Minato, T. Osa, Chem. Lett., 1987, 581

39a)I. Tabushi, N. Shimizu, T. Sugimoto, M. Shiozuka, K. Yamamura, J. Am. Chem. Soc., 99, 7100 (1977)

b) J. Boger, D.G. Brenner, J.R. Knowles, ibid ., 101, 7630 (1979)

40）松井佳久, 表面, 24, 332 (1986)

41a) Y. Matsui, T. Nishioka, T. Fujita, Topics in Current Chem., 128, 61 (1985)

b) C. Silipo, C. Hanch, Bioorg. Chem . , 8, 237 (1979)

42a)E. A. Lewis, L.D. Hansen, J. Chem. Soc ., Perkin Trans. II , 1973, 2081

b) R.I. Gelb, L.M. Schwartz, M. Radeos, R.B. Edmonds, D. A. Laufer, J. Am. Chem. Soc., 104, 6283 (1985)

c) G. Barone, G. Castronuovo, V. Elia, M. Muscetta, Thermochim. Acta, 85, 443 (1985)

d) 藤沢雅夫，木村隆良，高木定夫，第 7 回シクロデ キストリンシンポジウム予稿集，p.14（1988）

43) M. Sakurai, M. Kitagawa, H. Hoshi, Y. Inoue, R. Chujo, Chem. Lett., 1988, 895

44a) 原田一明, 澱粉科学, 26, 198 (1979)

b) 藤原隆二，日本結晶学会誌，24，54（1982） 
c) K. Harata, K. Uekama, M. Otagiri, F. Hirayama, J. Inclusion Phenom., 1, 279 (1984)

45a) M. Komiyama, H. Hirai, Bull. Chem. Soc. Jpn., 54,828 (1981)

b) Y. Inoue, H. Hoshi, M. Sakurai, R. Chujo, J. Am . Chem. Soc., 107, 2319 (1985)

c) Y. Yamamoto, Y. Kanda, Y. Inoue, R. Chujo, S. Kobayashi, Chem. Lett., 1988, 495 46a) M. Kajtar, Cs. Horvath-Toro, E. Kuthi, J. Szejtli, Acta Chim. Acad. Hung., 110, 327 (1982)

b) G.M. Bonora, R. Fornasier, P. Scrimin, U. Tonellato, J. Chem. Soc., Perkin Trans. II , 1985, 367

47a)服部憲治郎，高橋圭子，高分子，36，840（1987）

b)J. Szejtli, Starch, 39, 357 (1987)

\title{
「有機金属の化学」
}

\author{
山崎博史・若柣康雄 共著 \\ 大日本図書 発行 \\ B 5 版 216 ページ \\ 定価 3,000 円
}

本書は日本化学会の企画による大学低学年学生を対象 とした, 新化学ライブラリー (全 30 巻)のうちの 1 巻で ある。しかし，本書の対象は著者らがまえがきで断って いるように，むしろこれから化学を専攻しようとする大 学学部学生, 大学院学生, あるいは実社会で有機金属に 関連した仕事を始めようとする研究者，技術者など既に 一応の化学的知識をもった人々にとって，正に好書であ るという印象を持った。

近年の有機合成化学において, 種々の有機金属反応剤 の進歩には目覚ましいものがあり, 合成研究に携わる者 で何の金属にも関係しないでいるのは不可能と言っても 過言ではあるまい。むしろ, 周期率表の大半を占める種々 の金属元素について，その特性を正しく理解して反応設 計に利用していくことが今後の合成研究の一助となるは ずである。

研究の開始にあたって，金属をどの程度理解している
のかを確かめてみたい時，本書を一読することを扔勧め したい。評者自身, 本書を読んだ時, 日頃経験をもとに 何げなく行っている反応について，軌道の相互作用と いった見地から反応機構が議論されているのに新鮮な ショックを受けた。さらにその新しい視点から自分の反 応に関する新しい発想が湧いてくるというような体験 をきっと読者諸氏にも味わっていただけるものと思う。

書名を敢えて「有機合成の化学」とした点や, 巻頭の 種々のカラー写真など，かなり平易な本を装ってはいる が，その実，原理的な反応の本質を読者に理解させるた めに必要な化学的背景が十分に記載されており，骨太な 内容となっている。また, 1988 年の文献もかなり引用 されており，さらに話題が工業的な応用例や生体，材料 の分野におよんでいる点など，有機金属化学の分野にお ける新しい入門書を作り上げようとする，著者らの熱意 が強く感じられる好書である。

(富森浩二) 